\title{
The Economy of Memory: Archive-Driven Documentaries in the Digital Age
}

(as published in the Journal of Media Practice, JMP 14:3, October 2013)

Archive footage and photographs are an essential element of any historical film but the conditions of access, the limits of copyright and the cost of clearance and licensing have become increasingly complicated, making archive-driven films on low budgets increasingly challenging.

I experienced these problems first-hand on my recent archive-driven feature documentary Children of the Revolution (2010), which explores the history of Ulrike Meinhof and Fusako Shigenobu, two women inspired by the student revolutions of 1968 to overthrow capitalism through world revolution, as leaders of the Baader Meinhof Group and the Japanese Red Army. As half of the film consists of archive footage, clearing and licensing this material within my modest budget was the most time-consuming and challenging aspect of the production.

In this article, I'll explore the typical workflow for such a creative documentary and the industrial obstacles that make archive-driven historical films increasingly rare, unless commissioned by a broadcaster. I'll explore recent public policy initiatives in the area of copyright licensing and fair use and their potential impact on filmmakers and the commercial archive industry. I'll also consider alternative models for archivedriven historical films that stretch the form while skirting the clearance complications and expense of the standard industry model.

\section{The Process}

Where budgets allow, an Archive Producer is employed by a production solely to manage the archival elements of the film - to lead a team of archive researchers to source clips relevant to the subject, show them to the director, log their source and rights-holder and, if necessary, clear rights, negotiate license fees and order master materials for insertion into the finished film.

On smaller, independent films, it's common for a director like myself to absorb this role, searching our repositories of social memory for authentic images never broadcast before that illuminate and de-familiarise the subject without resorting to 
visual cliché; repeating archive used in previous productions; or cutting corners with slippages and substitutions (Chanan, 2007).

The initial search is largely dependent on the quality of the metadata and descriptions associated with relevant holdings in an archive's database. My film was co-produced with German broadcaster WDR and I spent many months searching for the original source of Ulrike Meinhof's most intimate and revealing interview before finding it tagged 'Ulrike - Konkret' rather than 'Ulrike Meinhof' in the WDR database (Meinhof was a journalist for konkret magazine before she went on the run in 1970).

Once you know which items you're interested in, you order screeners with burnt-in time code - which may need to be translated - and insert them as place-holders in your rough cut, to be replaced later, on payment of the license fee, with master footage.

As I was interested in the post-war period to the late seventies, all archive holdings were originally shot on film and many had not been viewed since the year they were recorded. Metadata for material still on film is gleaned from camera sheets, so if these are missing, a film can marked 'Jordan, 1970' may be all you have.

Commercial archives are now rapidly digitising their material, however and I got lucky when in 2009, AP Archive announced a major restoration project around a 'lost archive' of 'twenty-thousand film cans containing 3,500 hours of international news footage... lying dormant for decades deep underground in the Central London bunker from which Eisenhower directed the D-Day landings' (AP Archive, 2009). The films were well preserved but the text catalogues were scattered, so AP Archive assembled a team to reconfigure the paper records and 'create a coherent online text database'.

The period covered by this newly restored collection was a perfect fit for Children of the Revolution and we licensed pristine new HD transfers of rare $16 \mathrm{~mm}$ news-film sent from Japan in the late sixties at a bulk discount - footage of student demonstrations and capus occupations no longer held by Japanese broadcasters due to their poor preservation record.

\section{Rights Clearance}

Modern privacy and copyright laws make clearing archive material time-consuming and problematic. Contributor and crew agreements in 1970s Germany, for example, 
did not foresee programmes being resold in the future, so a tricky issue in licensing is clearing permission from key contributors retrospectively.

It's WDR policy to contact the commissioning editor who oversaw the original programme for permission and advice, and contact information for contributors; or failing this, to gain clearance from their successor. This takes time and they are also wary of breaching modern privacy laws or triggering residual claims by the original crew or contributors.

For these reasons, I could only clear the WDR footage in my film for television use, as it was felt broadcasting was the original intention of the programme - sales and distribution in other formats were not foreseen or explicitly agreed to. Hence, the television version of the film is four minutes longer than the version released in other media. Cutting the WDR interviews with Meinhof and her ex-husband Klaus Röhl has a significant effect on the DVD version but was unavoidable.

Children of the Revolution tells the stories of Meinhof and Shigenobu 'through the eyes of their daughters', Bettina Röhl and May Shigenobu. As joint-heir with her sister to her mother's estate, Bettina Röhl controls the use of her mother's words, image and intellectual property. This helps her control the discourse around her mother by controlling access to a large collection of photographs and home-movies that help a filmmaker tell her story.

During production, as Bettina demanded editorial control over how both she and her mother would be represented in the film, our access to these archive materials was withdrawn. There are only two other sources for key photographs of Meinhof's life: rival biographer Jutta Ditfurth and Ullstein Bild, part of the Springer empire Meinhof so despised and the publisher of Ditfurth's highly partisan biography. Images of Meinhof are now recognised by all parties as valuable commercial capital, storytelling tools to be withheld from rogue points of view and to be exploited for commercial gain.

Ditfurth, who sees Meinhof as a heroic figure, initially denied me access to her images because of the film's focus on Bettina, who sees her mother as a terrorist who went crazy underground. Several former Red Army Faction (RAF) members also refused to give interviews once Bettina was mentioned, as it was presumed the film 
would take her line. Access to archive and contributors on this subject is thus highly political, with contributors seeking control of the context in which archive is used or their views are expressed, with a preference for a supportive political line or a cast of like-minded characters. This of course has a profound effect on how the filmmaker can tell the story. Others were more pragmatic, admitting they now earn a living from interviews about the RAF.

In 2007, Bettina's family 'home movies' secured her a 24-minute film for Spiegel TV based on her book about her parents, Making Communism Fun. When Stefan Aust used the home movies without permission in his Die RAF documentary later that year, Bettina and her sister sued for breach of copyright and were awarded a substantial settlement. When Seven Stories Press published a collection of Meinhof's columns in English, Everybody Talks About the Weather...We Don't, the inclusion of an afterword by Bettina was a condition of publication (Bauer, 2008).

As negotiations with Bettina continued, she informed us that any published use of her mother's words was subject to copyright. We could license mute images from a broadcaster, but if Meinhof was heard speaking, her words should be licensed separately through Bettina and her sister. Quite aside from the questionable legality of this, the enormous extra cost involved was prohibitive. We could surely claim 'fair use' against the Meinhof estate's attempt to effectively silence their mother.

\section{Licensing Costs}

A BBC commission allows you free use of their archive for domestic broadcasts, which gives a filmmaker like Adam Curtis tremendous scope for his authored mashups on weighty psycho-historical themes. On the downside, none of Curtis' documentaries will ever be broadcast outside the UK or released on DVD because the cost of archive and music clearance would be enormous. To counter this, he personally endorses online bootlegging of his BBC broadcasts.

WDR and its sister stations in the ARD network operate a similar archive-sharing agreement for German filmmakers. They have a shared database and waive domestic license fees between sister stations, charging a flat 150 euro clearance fee for each programme used. Clearance gets complicated when you want to license archive for worldwide distribution in the normal cycle of film festivals, theatrical release, 
DVD/video-on-demand and all forms of television. Each of these distribution windows is classified as a separate licensing use, which must be paid for. The longer the term of the license and the more territories you need to clear, the more it costs (sales agents usually require a minimum five-year license period worldwide).

The cost of licensing archive is thus a major line item in any independently-produced historical documentary but it's notoriously difficult to budget archive-driven historical films because you only find a creative balance between interviews and the amount of archive material you need in the edit. You can only negotiate a discounted deal with an archive when you know how much of their material you need, and you only know for sure which territories to clear as sales are made after the completion of the film.

The simplest way to clear archive for blanket, unrestricted use is a ten-year license for all media worldwide but rate card prices for this start at $£ 4,000-5,000$ per minute. As over half my film is made up of archive footage, paying rate card would have exhausted my entire budget, so a lot of my time was spent doing deals and finding creative ways around this. A couple of examples illustrate the gulf in understanding between archives and producers regarding the commercial realities of a creative documentary.

Some of the key Meinhof footage owned by NDR and ARD News is licensed through Studio Hamburg, the archive division of a major German studio. When I finished the film, my only guaranteed broadcast was on WDR, so I planned to license the ARD archive under the ARD archive-sharing agreement initially, and then license for world use later when I got a sales agent and they began to sell the film internationally.

Studio Hamburg refused to clear just for Germany, fearing I would take the master footage and run. They insisted I clear my home country (the UK), negating the benefit of the German arrangement. As they knew it was premium footage I couldn't get elsewhere, there was no negotiation on price. I could either pay rate card prices or I wouldn't get the footage. Either I compromised the film by cutting the iconic footage of Meinhof or I paid the going rate. My co-production agreement with WDR gave ARD channels a seven-year unlimited license to screen my film, but I ended up paying more than half the co-production funding back to ARD channels to license twelve minutes of archive for worldwide use. 
In Japan, it was no different. Fuji Television (2009) quoted me $£ 20,000$ for one minute of footage from Fusako Shigenobu's only television appearance (Sanji no Anata, 1973) for worldwide use - assuming such 'highly political and sensitive' footage could be cleared - effectively suppressing it forever.

Once my film started selling internationally, it was instructive to compare the sales reports to what I'd paid for archive footage. I was very pleased to license pristine footage from a Scandinavian broadcaster at a fraction of their normal rate, but I later learned they had acquired my completed film for twice what I'd paid them for one minute of archive.

The critical misalignment between the price of archive footage and the acquisition prices paid by broadcasters is thus, the biggest challenge facing historical documentaries today. As we have seen, the ownership of the images to tell Ulrike Meinhof's story are closely guarded by family, rival authors, major studios and publishing houses, all controlling the conditions of use and trying to maximise profits. Without the economic capital offered by a commissioning broadcaster, it's becoming increasing difficult to tell these stories with fresh archive that reinvigorates the subject and overturns the cliches of the genre.

\section{The Commercial Archive Market today}

According to a recent report by Screen Digest (Harvey, 2010), nearly 43 million hours of content are held in the world's archives, generating $€ 430 \mathrm{~m}$ in revenue in 2009 , with television producers accounting for 55 per cent of sales, followed by corporate users, advertisers, educators and movie producers. News footage accounts for the bulk of revenue, with documentary footage the second most important genre of content. $87 \%$ of archive content has been catalogued and $61 \%$ has been made available online but just $21 \%$ has been cleared for licensing. As Harvey notes, access has improved but rights remain an issue.

The report highlights digital asset management, metadata and customer access portals as key areas to be addressed in improving the accessibility of archive material, noting the industry's 'innovative steps to try and address these issues [by] experimenting with user-generated metadata and providing advanced access portals that allow realtime clip selection and on-the fly transcoding' (Harvey, 2010). 
The interests of commercial archives are represented by FOCAL (The Federation of Commercial Audio Visual Libraries), who estimate the UK's commercial audiovisual archives contain over 17 million hours of footage, generating sales of over $£ 112$ million in 2011 (Best, 2012a).

In November 2010, just as I finished my film, David Cameron announced an independent review, chaired by Professor Ian Hargreaves, of how the UK's Intellectual Property framework supports growth and innovation. Hargreaves was previously editor of the Independent and New Statesman and director of BBC news and current affairs.

The Hargreaves Report, published in May 2011, made ten major recommendations to modernise UK copyright law in the commercial digital age and 'enhance the economic potential of the UK's creative industries' while ensuring digital innovation was not impeded by overprotection (IPO, 2011).

While FOCAL welcomed new measures to protect and police copyright, they warned two of Hargreaves' most contentious recommendations could cause the death of the commercial archive industry.

\section{Extended Collective Licensing}

One of Hargreaves' key proposals was the creation of a cross-sectoral Digital Copyright Exchange (DCE) to streamline the licensing process: 'a digital market place where licences in copyright content can be readily bought and sold, a sort of online copyright shop' (IPO, 2011).

The DCE would operate on the principle of Extended Collective Licensing, where third-party material is licensed from a standardised rate card through a collection agency and channelled back to its rights owner. The model for this is the music industry, where PPL and PRS administer recording and publishing rights from a centralised database on behalf of record labels, performers and songwriters.

While almost two thirds of UK archive content sales are made to UK companies, more than $80 \%$ of archive footage is licensed for cross-border use (Harvey, 2010). Hargreaves argued that by making cross-border licensing easier, the DCE offered 
'clear benefits to the UK as a major exporter of copyright works' in more open, efficient markets (2011: 8).

In their consultation submission, the BBC welcomed such an integrated copyright licensing regime "which reflects the needs of a digital converged world - a world increasingly dominated by high volume, low value transactions as opposed to the low volume, high value transactions which were a feature of the analogue era' (Hooper, 2012: 4).

While industry body FOCAL welcomed easier access to digital content through a centralised database - which could share and build metadata and help rights owners track copyright infringement - FOCAL lawyer Hubert Best strongly opposed extended collective licensing, arguing 'it would destroy archives' exclusive control of much of their footage [and] thus their ability to set the price and control the sales' (2012b: 7). Premium pricing would be replaced by a flat fee minus the collection agency commission, reducing income.

The government accepted Hargreaves' recommendations and asked Richard Hooper to lead a feasibility study into the DCE. Hooper's call for evidence was framed around the Hargreaves Hypothesis that 'Copyright licensing.... is not fit for purpose for the digital age' and highlighted the cost of licensing, difficulty of access and 'the misalignment of incentives between creators, rights owners, rights managers, rights users and end users' as key issues which 'deprived [the public of] access to a significant amount of commercially and culturally valuable content' $(2012: 21,25)$. The hypothesis claimed 'UK GDP should grow by an extra $£ 2$ billion per year by 2020, if barriers in the digital copyright market were reduced' (Hooper, 2012: 53).

Hubert Best's detailed response stressed increased digital access 'is a factor of investment' (2012a: 4). As of 2009, 40\% of archive content was held on digital tape and $10 \%$ on other HD sources; $20 \%$ was still on film and the rest was on analogue tape format. Best notes, 'archive footage which is held in analogue formats must be digitised, sometimes restored and/or preserved, and metadata must be created, to enable digital access. In the commercial archive sector, this is funded commercially out of sales/licensing' (2012a: 4, 6). 
The broadcast market is depressed, so archives see growth coming from digital markets - like video games, smartphone applications and Internet virals - and reinvest sales revenue to generate more digital content. Premium pricing drives increased digital access and the slow pace of digitisation is due to 'downward pressure on footage licence prices in the industry in recent years (from reduced production budgets, 'fair dealing' of footage where this is not legally justified but is uneconomic to pursue, and new BBC acquisition licensing practices)' (Best, 2012a: 4, 6).

Television is now watched across multiple platforms and time-shifted using iPlayer or Sky+ devices. Where previously, these ancillary platforms were priced separately, now the BBC requires producers to license a package of 'Public Service Rights' for blanket BBC use across all platforms. Best notes that as 'the largest commissioner of reused archive content...the BBC's market position is such that it could in effect impose this arrangement on commercial archives,' resulting in a 20\% drop in primary sales income that has hit the industry hard (2012a: 3, 7).

\section{Widening copyright exceptions}

FOCAL also vehemently oppose the widening of 'fair dealing' exceptions to copyright proposed by Hargreaves. Best argues archive footage is sold mostly in short clips under 30 seconds, so 'allowing marginally more use free of charge would affect footage archives disproportionately...[and] undermine incentives to produce digital content and make it available for digital consumers' (2012b: 3-4).

In the UK, Section 30 of the Copyright, Designs and Patents Act 1988 allows for certain copyright exceptions for the purposes of criticism or review, and reporting current events, provided the source is acknowledged and the work is publicly distributed. Such 'fair dealing' also depends 'on the extent of the use...the importance of what has been taken...[and] the degree to which a use competes with exploitation of the copyright work by its owner' (HM Government, 2012: 14).

Godard pioneered the principle of 'fair dealing' with his eight-part Histoire(s) $d u$ Cinema (1988-98), made on a very small budget for Canal Plus. Quoting liberally from myriad films, photos, texts and pieces of music to illustrate a personal history of cinema, Godard claimed his 'citations' were for science and scholarship, not commercial use, and so could be used for free. Brody writes that Godard told 
Gaumont head Nicolas Seydoux he was no longer a filmmaker, but 'a philosopher who uses a camera' (2008: 516).

When the French press asked Godard how he could possibly afford to clear the hundreds of clips in the series, Godard told them he would go to court, if necessary, to obtain the excerpts he needed and in the end, according to Rene Bonnell at Canal Plus, co-producer Gaumont gave its rights for free and 'for the others, we knew that no one would do anything to Godard' (Brody, 2008: 516).

Mark Cousins took the same approach with his recent 15-hour series The Story of Film: An Odyssey (2011), 'fair dealing' hundreds of film clips from commercially available DVDs while clearing permission, often personally, with the filmmakers. Experienced archive researcher James Smith worked on the series and, writing in the FOCAL newsletter about 'archive film's hottest topic', was won over to the legitimacy of 'fair dealing' in the educational context of such a 'film-school masterclass':

If The Story of Film had gone the conventional route and sought licences for every feature film clip, the budget would have been in the millions - many millions. Even then there would have been inexplicable refusals, lawyers demanding ridiculous fees for the estates of long dead third parties, all the usual pitfalls that would have led to multiple and tragic omissions in the story.

Fair Dealing is a fact, and it is used perhaps more than it should be...but if it is used for true journalistic reasons rather than an excuse to save costs on the wallpaper, then this film wins the argument over the law's existence hands down.

(Smith, 2012: 8-9)

The 'fair use' provision of US copyright law offers slightly wider exceptions than 'fair dealing' and was aggressively used by leading Hollywood attorney Michael Donaldson to clear over 900 video clips for eight films screened at Sundance in 2011 (Lindsey, 2011). In 2005, Donaldson helped The Center for Social Media (CSM) draft a 'Documentary Filmmakers' Statement of Best Practices in Fair Use' to protect filmmakers' 'free expression within copyright law' (CSM, 2005: 1), sparking a surge in the use of the practice. The statement notes:

...Judges decide whether an unlicensed use of copyrighted material is 'fair'... [and] generates social or cultural benefits that are greater than the costs it imposes on the copyright owner...[As documentaries] typically quote only short and isolated portions of copyrighted works...judges generally have 
honored documentarians' claims of fair use in the rare instances where they have been challenged in court.

(CSM, 2005: 1)

My sales agent for Children of the Revolution barred fair-dealt material because the principle of 'fair dealing' is not universally accepted and interpretation varies by jurisdiction. But the CSM statement claims 'fair use' can be applied to historical documentaries, given their 'social and educational importance' as long as:

The material serves a critical illustrative function, and no suitable substitute exists; the material cannot be licensed, or...can be licensed only on terms that are excessive relative to a reasonable budget for the film in question; the use is no more extensive than is necessary to make the point for which the material has been selected; the film project does not rely predominantly or disproportionately on any single source for illustrative clips; the copyright owner of the material used is properly identified.

(CSM, 2005; 6)

AP Archive's Alwyn Lindsey finds this statement 'deeply flawed' and one-sided, using 'idealist language about freedom of expression...to justify extensive and creative Fair Use in situations where the practice is purely about avoiding the payment of licence fees and maximising profits for content users' (2011: 11-12).

Filmmakers are not required by law to disclose 'fair use' to a rights holder, so Lindsey advocates 'a truly inclusive code of conduct that addresses the rights of all stakeholders - users and content owners alike... [and] a 'Fair Use/Fair Dealing Registry' where broadcasters obligate their producers to post their Fair Dealing claims so that rights holders... have an opportunity to challenge the use if they believe it to be outside of the exemption rules' (2011: 12).

As production budgets fall, Hubert Best says misuse of 'fair dealing' is a major problem. As only the largest archives can afford the expense of a complex infringement action, he fears widening copyright exceptions will 'open the floodgates' to much wider abuse (2012a, 8).

A commercial archive will only digitise content and invest in storage and metadata creation if it expects to make a commercial return. Faced with free re-use of archive, Best argues digitisation would stop and archives would withhold their footage offline and 'kill the digital supply' (2012a: 7). 


\section{Summary}

In its final response published December 20, 2012, HM Government announced plans 'to create a more general permission for quotation of copyright works for any purpose, as long as the use of a particular quotation is 'fair dealing' and its source is acknowledged' (2012: 4). This 'will remove unnecessary restrictions to freedom of expression and comment and will better align UK law with international copyright standards (2012: 28).

Addressing commercial archives' concerns, the response states a fair dealing exception 'will not apply if the use of such a clip would conflict with its normal [licensed use] or cause unreasonable harm to rights holders...particularly if the licence is easily available on reasonable and proportionate terms' $(2012: 14,27)$.

The UK's creative industries account for three per cent of the economy and are now working with Richard Hooper to create an industry-led Copyright Hub to collate, identify and license copyright works in a more user-friendly and cost-effective manner (HM Government, 2012).

Participation will be on a voluntary basis, with an opt-out provision for rights holders but FOCAL still insist the measures are 'constitutionally improper' (Best, 2012c, 2) and erode property rights protected under European human rights law - an ECL body 'would artificially distort the market for the rights since its rates would become the de facto standard against which negotiations would take place', notes Best, seriously weakening the creator's economic right 'to control the use of his own property and negotiate the price at which he is prepared to license it' $(2012 \mathrm{c}, 8)$. Best sees legal challenges to these new provisions as 'inevitable' $(2012 \mathrm{c}, 9)$.

In this atmosphere of suspicion and distrust, archives and filmmakers need to forge a better understanding of each other's commercial realities. Alwyn Lindsey's joint code of conduct may be a starting point but his 'Fair Use/Fair Dealing Registry' would only entrench the power of broadcasters and archives and further complicate licensing.

Lindsey cites 'the creation of programming based on Fair Dealing exemptions' as 'another worrying trend' (2011: 12) - Room 237 recently employed 'fair use' to critique multiple conspiracy theories around The Shining. In the current climate for 
creative documentaries, this seems to me a valid strategy to enable films of cultural and historical value that otherwise could not be made.

The key issue is price. Asked to justify why rights are so expensive, Best said price is determined by their fair market value. He claims 'the vast majority' of archive content is 'generic content which can be accessed from a number of sources,' creating price competition among suppliers and driving down prices (2012a, 3).

This is not my experience. Many creative documentaries draw on archive that is not generic and draws heavily on one collection or clips from specific films. Public broadcasters like the BBC may give a 10\% discount for several minutes of footage but they generally price re-use of their publicly funded programmes out of the range of most independent productions. They should show a more flexible approach to lowbudget films of cultural value.

Just as PACT and Equity have low-budget agreements for feature films with budgets under $£ 3$ million, reflecting the scale of a production, so archives should acknowledge the vast differences in what clients can pay. The current one-price-fits-all approach to filmmakers, irrespective of their budget and commercial potential, actively discourages films on history that don't fit the commissioning priorities of broadcasters. I'm in the same boat as Senna, produced by Universal and Working Title.

Hubert Best acknowledges that some archives offer reduced license fees in return for a share of profits (2012a). More flexible arrangements like this are needed to help archives and independent producers agree a fair commercial deal for licensing rather than exploiting 'fair use' out of budgetary necessity.

Archive-driven films are only possible on low budgets, if subsidized by cultural funding or a major broadcaster; or primarily working with 'public domain' or 'fair use' material. The cost ratio of commercial archive to the price paid for a creative documentary is not a sustainable business model - 'sliding scale' pricing structures would encourage historical documentaries that utilise our cultural heritage.

Hargreaves (2011) argues that copyright law should be liberalised and extended collective licensing implemented to standardise prices and simplify the licensing process. The commercial footage industry argues that it will only invest in digitisation of its archive materials if its exclusive copyright and right to premium pricing are 
protected. While digitisation increases the pool of historical evidence, such premium pricing limits its use and inhibits the wide distribution of archive-driven work like mine.

\section{Possible Solutions}

In the final section of this article, I'd like to consider alternative models for archivedriven historical films that stretch the form while skirting the clearance complications and expense of the standard industry model, drawing on my own work and that of filmmakers in the UK, Sweden, Serbia, Romania and Egypt.

My feature documentary RFK Must Die: The Assassination of Bobby Kennedy (2008) presents for the 'case for the defence' of convicted assassin Sirhan Sirhan, as Emile de Antonio and Mark Lane's Rush to Judgement (1967) presented the 'case for the defence' of Lee Harvey Oswald in the JFK assassination.

My film was constrained in its representation of Sirhan by a ban on media interviews with inmates by prison authorities in California, where Sirhan is still incarcerated; and the paucity of archive interviews available. Only two interviews have been filmed with Sirhan since his trial in 1969. The first, with NBC's Jack Perkins, was recorded the day after Sirhan received the death sentence (later commuted to life imprisonment) and broadcast as The Mind of an Assassin in May 1969; the second was recorded with David Frost for the syndicated Inside Edition in 1989. In between, an intermittent prison ban on media access and Sirhan's own reticence saw him disappear from television screens for twenty years.

Successive California governors have vetoed bills to restore media access to prisoners. Governor Schwarzenegger (2006) said, 'I do not believe violent criminals should be able to traumatize their victims a second time by having unfettered access to the media'. In September 2012, Governor Brown was equally dismissive: 'Giving criminals celebrity status through repeated appearances on television will glorify their crimes and hurt victims and their families' (2012).

As I couldn't interview Sirhan for my film, I licensed thirty seconds of the Perkins interview from NBC but the cost of using more was prohibitive. These interviews with Sirhan are rarely seen in documentaries due to the cost of licensing, extinguishing his voice from the debate on the assassination and the public consciousness. 
The only access to Sirhan the media has is at his parole hearings, currently scheduled every five years. For a long time, Sirhan did not attend these hearings because he felt he had no realistic hope of parole but in March 2011, Sirhan made a three-hour appearance with his new attorney William Pepper and spoke publicly for the first time in twenty years. It's instructive to analyse the conditions of access to this hearing, how footage of the hearing was used and how what Sirhan said was later reported.

Access to the hearing was restricted to 'representatives of the news media.' As the small hearing room only had space for a $\mathrm{CNN}$ reporter and his cameraperson, $\mathrm{CNN}$ operated a press pool, sharing footage with local network affiliates in the prison parking lot after the hearing.

The recent vetoed media access bill sought to broaden the term 'representative of the news media' beyond the mainstream news networks to 'a journalist who works for or is under contract to a newspaper, magazine, wire service, book publisher, or radio or television program; or who, through press passes issued by a governmental or police agency or through similar convincing means, can demonstrate that he or she is a bona fide journalist engaged in the gathering of information for distribution to the public' (Ammiano, 2011).

I was clearly in the latter category and had a hard time getting permission from the prison information officer as 'legitimate news media' but permission was finally given and a local cameraman I hired was allowed into the parking lot, to get a dub of the CNN footage of the hearing and to tape post-hearing interviews with Sirhan's attorney.

The 'pool feed' system for accredited news media illustrates where images go, who owns them and who can access them after the daily news cycle. My cameraman was the only one to insist on a full copy of the parole hearing. As it was already dark and this would have meant a real-time three-hour recording in a broadcast truck, CNN agreed to send me a free dub of the hearing the next day.

The local affiliates were happy to take selected highlights to illustrate brief news stories the next morning. They didn't have time to watch the hearing themselves. The clips CNN provided set the tone for all subsequent media coverage, which devolved into visual cliché: the assassin apologises, the assassin argues with the parole board, the parole board puts him in his place. In pulling out the juiciest, most dramatic moments of 
the hearing, these brief reports misrepresented Sirhan's appeal argument and portrayed him as a loner, still full of hate after all these years, in line with his prosecutorial depiction. A three-hour hearing was reduced to a couple of misleading sound bites and Sirhan's side of the story remains untold.

A couple of days later, the hearing was no longer news and only CNN and I had full copies of the proceeding. These daily pool feeds provide lucrative archive material for the commercial footage arms of major broadcasters and the hearing footage can now be licensed through CNN ImageSource by those who can afford the hefty license fee.

I now have a three-hour recording of the hearing to draw on, free-of-charge, in a followup film on the case. What should I do with this three-hour recording? CNN will never broadcast it, so only I am free to distribute Sirhan's side of the story. Do I stream it for free online in a raw form that few will watch in its entirety? Do I re-package it into a new film on the Sirhan case that fits a slot in the television schedules? Or do I make a more subjective film for a niche audience who will pay to stream it online?

The Mosireen non-profit media collective in Cairo have shown how independent filmmakers can intervene to challenge not just the state narrative but the establishment media ownership of such images. Mosireen was 'born out of the explosion of citizen media and cultural activism in Egypt during the revolution. Armed with mobile phones and cameras, thousands upon thousands of citizens kept the balance of truth in their country by recording events as they happened in front of them, wrong-footing censorship and empowering the voice of a street-level perspective' (About Mosireen, 2013).

Mosireen collect and host a public archive of footage of the revolution, free to download and use on a creative commons basis, and also available for commercial use. They quickly became the most-watched non-profit Youtube channel in Egypt and host openair screenings of revolutionary footage in Tahrir Square. They pursue the goals of a new society and social justice through citizen media, filming and publishing footage of the ongoing revolution, and training activists to film, edit and upload their footage to social media in workshops across Egypt, recalling the work of earlier citizen media groups like Newsreel in the late sixties.

\section{New trends in the creative use of archive in storytelling}


Alongside the current vogue for historical films without narration, there is also a trend for films that represent the past through archive alone. Senna (2010) is the most successful recent example of this but it was originally conceived as a conventional mix of archive and interviews. Interviews with contributors were filmed but director Asif Kapadia and his editors decided to immerse the audience in the world of Senna (through archive) for the whole film, using only the audio of the interviews as commentary. During a workshop at the Archive Film Festival (2012), archive producer Paul Bell revealed that the film's producers at Working Title and Universal argued for the inclusion of on-screen interviews but Kapadia resisted and the film's success can be traced to the emotional engagement of the audience immersed in Senna's story.

Access was crucial. The rights to all Formula One footage are owned by Bernie Ecclestone's governing body and all footage of the late Ayrton Senna was subject to the approval of his family. Once Kapadia won the family's trust, the underlying rights were cleared through one entity who wanted to support a film that would honour one of its greatest stars. 2000 hours of archive material were distilled into a compelling narrative with the emotional arc of a three-act dramatic feature, the ghost of Senna informed by the audio commentary of close family and associates.

Black Power Mixtape 1967-1975 (2011) adopts a similar strategy. The story of the Black Power movement in the US is told through archive footage shot by Swedish reporters for national broadcaster SVT at the time. Filmed interviews with Stokely Carmichael, Eldridge Cleaver, Bobby Seale, and Angela Davis are intercut with footage from Lars Ulvestam's controversial film Harlem: Voices, Faces, and as the opening captions state, 'the film...does not presume to tell the whole story of the Black Power Movement, but to show how it was perceived by some Swedish filmmakers'. The interaction between subject and object as the Black Power leaders try to explain their movement to a curious Other is a fascinating aspect of the film.

On the audio track, contemporary interviews with principals like Davis provide occasional commentary while music cues separate the film into nine chapters and give it a mixtape feel, rather than a traditional narrative.

Director Göran Hugo Olsson found this rich seam of material while researching an earlier film on Philadelphia Soul music and it struck a chord. In his Director's Notes, 
Olsson describes his school years in the seventies as 'infused with a sense of solidarity with liberation movements':

Many of my classmates were children of Holocaust survivors or expelled Jews from the 1968 pogroms in Poland, others were part of the AllendeChilean exile community living in Sweden. We raised monies for the ANC after the Soweto uprising in South Africa, and in 1980-81 all of us were engaged in support work for the Solidarity strikes in Poland. My own consciousness was deeply affected by these struggles.

The mixtape format of Olsson's film - curating interviews and letting them run in much longer form than usual for documentaries - is an admission that the power of these fragments is most potent when they are unmediated, letting the images and times speak for themselves, as the viewer makes their own associations with cultural differences in the interim. As Olsson notes:

I wanted to keep the feeling of the material, not cut it into pieces...I decided to riff on the popular '70s 'mixtape' format, which I feel will appeal aesthetically and formally to younger generations, and to include audio interviews with key contemporary figures to complement the unusual beauty of $16 \mathrm{~mm}$ archival, putting the images in context and creating a formal mosaic that is uplifting and moving in impact.

(2011: 6)

As almost all images were owned by SVT, the archive could be licensed in bulk from one source and although Olsson credits himself as writer and director, he takes the unusual step of not just thanking but crediting personally the 'filmmakers, journalists and activists who created the footage' at the end of the film.

After distributing my own film Children of the Revolution in 2011, last year I distributed two more archive-driven films, which had successful theatrical runs at the ICA in London. Celine Dahnier's Blank City (2010) tells the story of New York's No Wave film scene in the late seventies, tracking down 'lost' prints of long-neglected underground films no longer owned by their directors to document a movement that gave rise to such talents as Jim Jarmusch and Steve Buscemi.

Cinema Komunisto (2010) by Serbian director Mila Turajlic tells the history of Tito's Yugoslavia through its movies. The film starts with a quote from Jacques Ranciere - 
'The history of cinema is the history of the power to make history' - and uses feature films made under Tito to tell, rather than just illustrate the story.

In the press kit for the film, Turajlic describes a year spent collating and cataloguing 320 films in the archives in Belgrade and bartering rare footage with private collectors. Trawling through long-neglected films, outtakes and discarded reels, she built a database 'of around 1500 clips from feature films, [indexed] by type of scene and dialogue...so that in the edit room I could find things quickly - for example, if we decided to do a montage of 'funny deaths from partisan films,' I could just enter those search words and I'd get 50-60 such scenes' (2011: 15).

Turajlic describes her archive search as 'a lot like detective work' (2011: 15). Often, one retired worker from the archive would have an encyclopedic knowledge of the collection in their head, not on paper, so charming them into cooperating was more effective than quizzing current archivists or wading through scattered and incomplete catalogues. As Turajlic notes, 'A lot of stuff disappeared or was burned in the bombing in the 90s, so often there was no way of knowing what was in a box or vault, and I just persuaded them to let me look at everything - that's how we found some incredible archive no one's ever seen before' (2011: 15).

After a year's lobbying, Turajlic was granted access to Tito's personal archive and only then did she realise how involved he had been in the films 'from copies of film scripts where he wrote his notes in the margins, to telegrams film directors sent him from film labs reporting on the first print of a film [and] transcripts of his conversations with filmmakers following screenings of rough cuts' (2011: 8).

The archive used counterpoints the 'official narrative' approved by Tito in partisan feature films - Richard Burton plays Tito in one state-funded epic - with revealing behind-the-scenes footage showing Tito's presence on set and young conscripts spending their entire military service playing German extras in war films glorifying Tito and the liberation of Belgrade.

For the first time, the Yugoslav Newsreels - the largest archive in the Balkans - gave Turajlic permission 'to take dozens of reels out of their vault for digital scanning. The result is that Tito and Yugoslavia pop on the big screen like never before' (2011: 8). 
As these materials were being licensed for the first time, the archive had little idea of their commercial value, so they could be licensed in bulk for a flat fee at a fraction of the cost charged by more commercially evolved western archives.

Andrei Ujica's The Autobiography of Nicolae Ceausescu (2010) also uses 'the archive of the life of a head of state' (Rau, 2010: 1) to show the story Ceausescu told Romanian people about himself, unmediated by narration or interviews with former colleagues but bookended by news footage of Ceausescu's downfall and arrest.

Funded by French and German public subsidies, the film draws on one thousand hours of archive footage from the Romanian National Film Archive and state broadcaster SRTV. Two researchers filtered this down to 250 hours, which Ujica watched 'scrupulously, hour by hour, like a clerk going to the office every day' (Rau, 2010: 1). Watching the 'protocol, ritualized images' of Ceaușescu for eight hours a day, Ujica fixated on:

The so-called remains, at the beginnings and endings of reels, [which] preserve the genuine moments [when Ceaușescu] is - before knowing he is being filmed and after he thinks the shooting has stopped - his true self, whatever that means. I kept mainly these moments, which are, astonishingly, quite many. And that's how you start to get to know someone. After a while...you start to understand his micro-gestures, his body language, the inflections of his voice...His image became human.

(Rau, 2010: 1)

Ujica feels his film proves, 'that today, using only archive images, it is possible to make a film on recent history in an epic vein similar to that of historical fiction cinema...where montage plays a two-fold part: mise-en-scene, as it builds scenes that do not exist as such in the rushes, and classical editing, connecting scenes together' (2010: 2). 


\section{REFERENCES}

Ammiano, T., (2011) AB-1270 Prisons: media access, Available at:

http://leginfo.legislature.ca.gov/faces/billNavClient.xhtml?bill_id=201120120AB127

$\underline{0},($ accessed $20 / 1 / 13)$

AP Archive, (2009) The Lost Archive - Historic Time Capsule of News Footage

Recovered by AP, Available at: http://www.focalint.org/industry-news/news/

127/historic-time-capsule-of-news-footage-recovered-by-ap, (accessed: 1/9/12)

The Autobiography of Nicolae Ceausescu (2010) Directed by Ujica, A. [DVD

screener] Romania: Mandragora International

Best, H., (2012a) FOCAL response to DCE Feasibility Study Call for Evidence, Available at:

http://www.focalint.org/assets/files/focal international dce response_20120216.pdf, (accessed: 1/9/12)

Best, H., (2012b) FOCAL response to Hargreaves Copyright Review, Available at: http://www.focalint.org/assets/files/focal_international_response_to_copyright_revie w_20120321.pdf, (accessed: 1/9/12)

Best, H. (2012c) Letter to Joint Committee on Human Rights, House of Commons, Available at: http://www.parliament.uk/documents/joint-committees/humanrights/Hubert_Best.pdf, (accessed: 15/12/12)

Black Power Mixtape 1967-1975 (2011) Directed by Olsson, G.H., [DVD] Sweden: Soda Pictures

Blank City, (2010) Directed by Danhier, C. [DVD] USA: E2 Films

Brody, R., (2008) Everything is Cinema - The Working Life of Jean-Luc Godard, London: Faber and Faber

Center for Social Media (CSM), (2005) Documentary Filmmakers' Statement of Best Practices in Fair Use, Available at:

http://www.centerforsocialmedia.org/sites/default/files/fair_use_final.pdf, (accessed: $1 / 12 / 12)$ 
Chanan, M., (2007) The Politics of Documentary, London: BFI

Children of the Revolution, (2010) Directed by O'Sullivan, S. [DVD] UK: E2 Films

Cinema Komunisto (2010) Directed by Turajlic, M. [DVD] Serbia: E2 Films

Hargreaves, I. (2011) Digital Opportunity: A Review of Intellectual Property and Growth, Newport: The Intellectual Property Office, Available at:

http://www.ipo.gov.uk/ipreview-finalreport.pdf, (accessed: 1/5/12)

Harvey, C., (2010) The Global Trade in Audio-visual Archives, Available at http://www.screendigest.com/reports/201074c/10_08_the_global_trade_in_audio_vis ual_archives/view.html, (accessed: 1/9/12)

HM Government, (2012) Modernising Copyright: A modern, robust and flexible framework, Newport: The Intellectual Property Office, Available at:

http://www.ipo.gov.uk/response-2011-copyright-final.pdf, (accessed: 21/12/12)

Hooper, J. and Dr. R. Lynch, (2010) Rights and Wrongs: Is copyright licensing fit for purpose for the digital age?, Newport: Intellectual Property Office, Available at http://www.ipo.gov.uk/dce-report-phase1.pdf, (accessed 1/9/12)

IPO (Intellectual Property Office), (2011) The Hargreaves Report shows potential to boost economy, Available at: http://www.ipo.gov.uk/about/press/press-release/pressrelease-2011/press-release-20110518.htm, (accessed: 1/5/12)

IPO (Intellectual Property Office), (2012) Consumers given more copyright freedom, Available at: http://www.ipo.gov.uk/about/press/press-release/press-release2012/press-release-20121220.htm, (accessed: 21/12/12)

Lindsey, A., (2011) 'Fair Dealings Use Of Someone For Financial Gain Without Permission', Archive Zones, 77, pp. 10-12, Available at:

http://publications.focalint.tv/ArchiveZones/az2011spring_iss77_fair_dealings_use_o f_someone_for_financial_gain_without_permission.pdf, (accessed: 1/9/12)

Mosireen (2013), About Mosireen, Available at: http://mosireen.org/?page id=6, (accessed: 20/1/13) 
Olsson, G.H., (2011) Black Power Mixtape 1967-1975 Press Kit, Available at: http://blackpowermixtape.com/resources/index.php?file=BMP_1967-1975_PKIT.pdf, (accessed 16/6/12)

Rau, M., (2010) '1000 Hours of Ceaușescu', Available at: http://www.theautobiography.com/pliant.pdf, (accessed 18/1/13)

Röhl, B., (2006) So Macht Kommunismus Spaß: Ulrike Meinhof, Klaus Rainer Röhl und die Akte Konkret, [Making Communism Fun] Hamburg: Europäische Verlagsanstalt

Room 237, (2012) Directed by Ascher, R. [Film] USA: Metrodome Sanji no Anata, (1973) [DVD screener] Japan: Fuji Television, First transmission: $14 / 8 / 73$

Senna (2010) Directed by Kapadia, A., [DVD] UK: Universal Pictures

Smith, J., (2012) 'The Story Of Film - a Fair Deal for All', Archive Zones, 81, pp. 89, Available at: http://www.focalint.org/news-and-journal/archive-zonesjournal/archive-zone-issue/84/spring-2012-issue-no-81, (accessed: 1/9/12)

Turajlic, M., (2011), Cinema Komunisto Press Kit, Available at: http://www.cinemakomunisto.com/wp-content/uploads/2010/11/Cinema-KomunistoEPK-ENGdec2011.pdf, (accessed 1/5/12)

Ujica, A., (2010) The Autobiography of Nicolae Ceausescu Press Kit, Available at: http://www.the-autobiography.com/pliant.pdf, (accessed 18/1/13)

Ulrike Meinhof, Klaus Rainer Röhl und die Akte Konkret, (2007) [DVD screener] Germany: Spiegel TV, First transmission: 12/2/07 


\begin{abstract}
In the world of the historical documentary, the archive footage arms of large media corporations control our access to images from the past. This article explores whether archive-driven historical films are possible on low budgets, discussing the strategies used to research, clear and license footage for my recent archive-driven feature documentary Children of the Revolution (2010). I note the critical misalignment between the cost of licensing archive footage and the production budgets and prices paid for creative documentaries by broadcasters.

On a broader level, I examine public policy towards these repositories of historical evidence and analyse the hypothesis of the recent Hargreaves Report (2011), that 'Copyright licensing [in the audiovisual archive sector] is not fit for purpose for the digital age' (Hooper, 2012: 21). I also consider alternative models for archive-driven historical films that stretch the form while skirting the clearance complications and expense of the standard industry model.
\end{abstract}

\title{
KEYWORDS
}

History

Documentary

Archive Footage

Archive Licensing

Rights Clearance

Fair Dealing 